\title{
Taitaia, a novel lichenicolous fungus in tropical montane forests in Kenya (East Africa)
}

\section{Suija, Ave}

2018-03-19

Suija , A , Kaasalainen , U S , Kirika , P \& Rikkinen , J K 2018 , ' Taitaia, a novel lichenicolous fungus in tropical montane forests in Kenya (East Africa) ' , Lichenologist, vol. 50 , no. 2 , pp. 173-184 . https://doi.org/10.1017/S0024282918000026

http://hdl.handle.net/10138/298260

https://doi.org/10.1017/S0024282918000026

acceptedVersion

Downloaded from Helda, University of Helsinki institutional repository.

This is an electronic reprint of the original article.

This reprint may differ from the original in pagination and typographic detail.

Please cite the original version. 
Published in: Suija A, Kaasalainen U, Kirika PM, Rikkinen J. 2018. Taitaia, a novel lichenicolous fungus in tropical montane forests in Kenya (East-Africa). The Lichenologist 50(2): 173-184. doi:10.1017/S0024282918000026

Taitaia, a novel lichenicolous fungus in tropical montane forests in Kenya (EastAfrica)

Ave Suija ${ }^{1}$, Ulla Kaasalainen ${ }^{2,3}$, Paul Muigai Kirika ${ }^{3}$, Jouko Rikkinen ${ }^{3,4 .}$

${ }^{1}$ Institute of Ecology and Earth Sciences, University of Tartu, Lai Street 40, EE51005, Estonia.E-mail: ave.suija@ut.ee

${ }^{2}$ East African Herbarium, National Museums of Kenya, Museum Hill Road, P.O. Box 45166, 00100 Nairobi, Kenya

${ }^{3}$ Finnish Museum of Natural History, University of Helsinki, P.O. Box 7, FIN-00014 Finland.

${ }^{4}$ Department of Biosciences, University of Helsinki, P.O. Box 65, FIN-00014 Finland

\begin{abstract}
During lichenological explorations of tropical montane forests in Kenya, a remarkable new lichenicolous fungus was repeatedly found growing on thalli of the epiphytic tripartite cyanolichen Crocodia cf. clathrata. Molecular phylogenetic analyses placed the fungus within Gomphillaceae (Ostropales, Lecanoromycetes), a family mainly of lichen-symbiotic species in the tropics. The anatomical features (unitunicate, non-amyloid asci and simple, septate paraphyses) as well as the hemiangiocarpic ascoma development confirm its taxonomic affinity. DNA sequence data showed the closest relationship was with Gyalidea fritzei, followed by Corticifraga peltigerae. A monotypic genus, Taitaia, is introduced to incorporate a single species, T. aurea. The new fungus is characterized by aggregated ascomata with yellow margins and salmon red discs developing from a single base.
\end{abstract}

Key words: Ascomycota, Corticifraga, Gyalidea, lichen-inhabiting fungi, Taita Hills, taxonomy 


\section{Introduction}

The diversity of lichenicolous fungi in Africa is largely underexplored and the limited information available is scattered in the literature (e.g. Bock et al. 2007; Ertz 2009; Fryday 2015). Thus, we can expect to find a plethora of taxa among the lichenized and lichen-inhabiting fungi that live in the many habitat types unique to Africa. The Taita Hills in south-eastern Kenya form the northernmost section of the Eastern Arc Mountains which, together with nearby coastal forests, represent a hotspot of global biodiversity (Myers et al. 2000; Burgess et al. 2007; Dimitrov et al. 2012). The moist and relatively cool conditions support a high diversity and considerable biomass of cryptogamic epiphytes (e.g. Enroth et al. 2013; Malombe et al. 2016; Stam et al. 2017). Even among macrolichens, many local taxa cannot be readily identified with the keys currently available for East Africa (Swinscow \& Krog 1988).

In the framework of lichenological exploration of tropical montane forests in Kenya, a remarkable lichenicolous fungus was repeatedly found growing out of the thalli of the tripartite cyanolichen Crocodia cf. clathrata (Peltigerales, Lecanoromycetes). Species of Peltigerales are known to host a large diversity of lichenicolous fungi of different phylogenetic origins (e.g. Kondratyuk \& Galloway 1995; Hawksworth \& Miadlikowska 1997; Lawrey \& Diederich 2016) but none of the available descriptions correspond with our new fungus. To clarify the systematic position of the unknown fungus, we analyzed its morphology as well as slow-evolving ribosomal and mitochondrial markers, and describe a new genus and species based on the results.

\section{Material and methods}

\section{Sampling sites}

Cyanolichen specimens infected by the new fungus were collected from montane forests in the Taita Hills and the western part of the Rift Valley. The Taita Hills rise abruptly from the surrounding dry plains at c. $600-1000 \mathrm{~m}$ to a series of mountain ridges, reaching $2208 \mathrm{~m}$ at the highest peak Vuria. The upper slopes of East African mountains benefit from moisture brought by the trade winds and capture enough of this to sustain moist evergreen montane forests. The moist and relatively cool climate provides favourable conditions for the development of species-rich bryophyte and lichen communities and considerable epiphyte biomass (Fig. 1). The type locality of the new fungus is located close to the summit of Vuria, in a dense 
indigenous forest dominated by Maesa lanceolata, Nuxia congesta and Dracaena afromontana.

\section{Morphology}

Light microscopy was carried out using hand-cut sections mounted in either tap water, a $10 \%$ aqueous solution of potassium hydroxide $(\mathrm{KOH} ; \mathrm{K})$, Cresyl blue (CRB), Congo red or in Lugol's solution (I). The apical apparatus of the ascus was observed in Lugol's solution (I) pretreated with $\mathrm{K}$ (denoted as K/I). The measurements were made in water and the sizes are presented as minimum(mean $\pm 1 \mathrm{SD}$ )-maximum value. The close-up photographs of ascomata and thallus cross-sections were taken using a microscope equipped with a Canon 60D digital camera. For the images, a series of up to 57 photomicrographs at different focal planes were stacked using HeliconFocus 4.45. The fluorescence microscopy, used to observe the pigments in the host thallus and in ascomata of the lichenicolous fungus, was carried out with a Zeiss Axioskop 40 FL microscope, an AxioCam MRc camera and the AxioVision 1.6. For the scanning electron microscopy (SEM), pieces were fixed onto an SEM-mount, sputter-coated with a $12 \mathrm{~nm}$ thick coating of $\mathrm{Pt} / \mathrm{Pd}$ using an Automatic Sputter Coater (Canemco Inc.), and examined and imaged with a Carl Zeiss LEO 1530 Gemini field emission scanning electron microscope.

The material studied is deposited in the herbarium of the National Museums of Kenya (EA) and in the lichen herbarium of the Natural History Museum at the University of Tartu (TU).

\section{DNA extraction, PCR amplification and sequencing}

Genomic DNA was extracted from ascomata of specimens using High Pure PCR Template Preparation Kit (Roche Applied Science ${ }^{\circledR}$ ) and following the protocol provided by the manufacturer with minor modifications. We amplified three gene loci: the internal transcribed spacer (ITS), the large subunit nuclear ribosomal RNA gene (nuLSU), and the mitochondrial small subunit ribosomal RNA gene (mtSSU). The primers used for amplification and sequencing were ITS0F, LA-W (Tedersoo et al. 2008), ITS4 and ITS5 (White et al. 1990) for ITS, LROR and LR5 (Vilgalys \& Hester 1990) and CTB6 (Garbelotto et al. 1997) for nuLSU, and mrSSU1 and mrSSU3R (Zoller et al. 1999) for mtSSU. The PCR reaction mix $(25 \mu l)$ consisted of $5 \mu \mathrm{l} 5 \times$ HOT FIREPol Blend Master Mix (Solis BioDyne, Tartu, Estonia), $0.5 \mu \mathrm{l}$ of 
$20 \mu \mathrm{M}$ of both primers, $1-8 \mu \mathrm{l}$ of target-DNA and distilled water. The PCR products were visualized in a $1 \%$ agarose gel stained with ethidium bromide. For the purification of PCR products, $1 \mu \mathrm{l}$ of FastAP and $0.5 \mu$ l of Exonuclease I (Thermo Scientific, Waltham,MA, USA) were added to each tube per $20 \mu 1$ of product. Both complementary strands were sequenced by Macrogen Inc. (Amsterdam, The Netherlands). Sequencher 4.10.1 (GeneCodes Corp.®, Ann Arbor, MI, USA) was used to check, assemble and manually adjust the resulting sequence fragments. The consensus sequences were compared with those publicly available in NCBI (https://www.ncbi.nlm.nih.gov/genbank) using a BLAST search to confirm their identity. For each gene, the top-scoring match was a member of Ostropomycetidae, even if the similarity did not exceed 90\%. The newly generated sequences are available in NCBI (https://www.ncbi.nlm.nih.gov/genbank) under Accession numbers MF372796-MF372801 and MF509277 (Table 1).

\section{Phylogenetic analyses}

The newly generated nuLSU and mtSSU sequences were aligned with sequences downloaded from NCBI (Table 1) using MUSCLE (Edgar 2004). We did not use ITS sequences in the analyses due to their high variability at higher taxon levels. The alignments were manually checked and trimmed with SeaView v.4.6 (Gouy et al. 2010). The first analysis included representatives of major classes of Ascomycota and subclasses of Lecanoromycetes, but focusing on Ostropomycetidae (data not shown). After the first analysis, we excluded sequences with ambiguous alignment and reduced the dataset, but left a representation of families of Ostropales. The online version of Gblocks v.0.91b (Talavera \& Castresana 2007) run at http://molevol.cmima.csic.es/castresana/Gblocks_server.html was used to eliminate poorly aligned positions and divergent regions of the alignment while allowing gap positions within the final blocks. For each gene, the best-fit nucleotide substitution model was calculated and selected based on the lowest value of AIC criterion with jModelTest v.2.1.6. (Darriba et al. 2012). The best-fit model for nuLSU was $\mathrm{TIM}+\mathrm{I}+\mathrm{G}$ and for $\mathrm{mtSSU}$ it was TVM+I+G. Each gene locus was aligned and analyzed separately with a maximum likelihood (ML) approach using PHyML (Guindon et al. 2010) and, as no topological conflict was detected in supported clades (bootstrapping over 100 replicates) by visual inspection (data not shown), nuLSU and mtSSU alignments were concatenated. The Markov chain Monte Carlo (MCMC) 
approach using MrBayes v.3.2.1 (Ronquist et al. 2012) was applied to reconstruct phylogeny. For the final partitioned analysis, two parallel simultaneous runs with four chains run were applied over $7 \mathrm{M}$ generations until convergence of the chains was confirmed by the standard deviation of split frequencies reaching 0.01 . The first $25 \%$ of saved data was discarded as burn-in, and the $50 \%$ majority-rule consensus tree and posterior probabilities (PP) were calculated from the rest. As an alternative, a maximum likelihood (ML) analysis using $\mathrm{GTR}+\mathrm{G}$ as the substitution model was implemented with RAxML v.8.1.10 (Stamatakis 2014) at the CIPRES Science Gateway (Miller et al. 2010). Bootstrap support (BS) was calculated from over 500 pseudoreplicates. The outgroup included Loxosporopsis corallifera Brodo et al., Dibaeis baeomyces (L. f.) Rambold \& Hertel (Pertusariales, Lecanoromycetes), Peltula auriculata Büdel et al. (Lichinomycetes) and Geoglossum nigritum (Pers.) Cooke (Geoglossomycetes).

The phylogenetic tree was visualized with FigTree v.1.4.2 (http://tree.bio.ed.ac.uk/) and Adobe Illustrator CS3® was used for artwork.

\section{Results and Discussion}

The combined nuLSU + mtSSU dataset consisted of 912 characters, 366 of which were nuLSU and $530 \mathrm{mtSSU}$. The singlegene and concatenated nuLSU + mtSSU analyses placed the sequences within Gomphillaceae, Ostropales ( $\mathrm{PP}=1, \mathrm{BS}$ =100; Fig. 2). The combination of phenotypic characters (hemiangiocarpic ascomata with non-amyloid asci without distinct apical apparatus; see Taxonomy, Fig. 4) supports the phylogenetic placement within Ostropales (Lumbsch et al. 2007; Jaklitsch et al. 2016), an ascomycete order of various lifestyles, including symbiotic, optionally lichenized and lichen-dwelling fungi (Baloch et al. 2010).

The family Gomphillaceae includes mainly lichen-symbiotic species distributed in the tropics and variously growing on, for example, living leaves, tree bark, bryophytes and soil or rock (Lücking et al. 2004; Baloch et al. 2010; Jaklitsch et al. 2016). In addition to the new fungus, only two other genera of lichen-inhabiting fungi are currently known in the family, Gyalideopsis Vězda (Etayo \& Diederich 2001; Etayo 2010) and Corticifraga D. Hawksw. \& R. Sant. (Pino-Bodas et al. 2017). The phylogenetic concept of Gomphillaceae itself has remained obscure and unresolved (Lücking et al. 2004). The family includes taxa previously placed in a separate family, Asterothyriaceae, distinguished by simple, unbranched paraphyses in 
the hamathecium and by the lack of hyphophores (Vězda 1987; Henssen \& Lücking 2002). Both of these characters are also observed in our new fungus (see Taxonomy). Considering the proportion of publicly available sequences (Table 1) and the number of species and genera currently assigned to Gomphillaceae (Jaklitsch et al. 2016), a re-evaluation of these two families can be expected in the future.

The new fungus, represented in the phylogeny by three specimens, showed the closest relationship to Gyalidea fritzei (Stein) Vězda ( $\mathrm{PP}=0.98, \mathrm{BS}=78$; Fig. 2). The two fungi have different ecologies, with the latter species being lichenized and growing on lime-rich stone (Gilbert et al. 2009). Both species in turn are sister to Corticifraga peltigerae $(\mathrm{PP}=0.98, \mathrm{BS}=80$; Fig. 2), another lichenicolous fungus which was recently shown to be a member of Gomphillaceae (Pino-Bodas et al. 2017). Similar to the new fungus, the species of Corticifraga live on cyanolichens of the Peltigerales (e.g. Hawksworth \& Santesson 1990; Zhurbenko 2007). All three genera share similar ascoma development, ascus arrangement, simple, septate paraphyses and colourless, ellipsoid to fusiform septate ascospores (Hawksworth \& Santesson 1990; Gilbert et al. 2009). Both the new fungus and Corticifraga have a similar type of exciple consisting of more or less globular cells (i.e. textura globularistype) (Hawksworth \& Santesson 1990); no information is provided about the exciple type of Gyalidea (e.g. Gilbert et al. 2009). Both Corticifraga and Gyalidea differ from the new fungus by having ascomata that arise singly, that are immersed, pale cream to almost black and with discs that are deeply concave (urceolate) to plane when mature (Hawksworth \& Santesson 1990; Gilbert et al. 2009).

\section{Taxonomy}

Taitaia Suija, Kaasalainen, Kirika \& Rikkinen, gen. nov.

MycoBank No.: MB 821739 - Type species: Taitaia aurea Suija, Kaasalainen \& Rikkinen

Taitaia aurea Suija, Kaasalainen \& Rikkinen, sp. nov.

MycoBank No.: MB 821740

DNA barcode/reference sequence (rDNA ITS): MF372800 (from holotype: Rikkinen 16258, DNA sample: AF259) 
Lichenicolous fungus. Ascomata apothecioid, hemiangiocarpic, breaking through cortex of host thallus, sometimes with ten or more ascomata arising from a single base, margins yellow and disc salmon red. Hymenium with unitunicate nonamyloid asci and simple, septate paraphyses. Ascospores fusiform and 1-septate.

Type: Kenya, Taita-Taveta Province, near summit of Vuria, dense moist forest with Maesa lanceolata, Nuxia congesta and Dracaena afromontana, UTM 421443, 9623094, 2072 m, on thallus of Crocodia cf. clathrata growing on stem of woody climber, 15 January 2015. J. Rikkinen 16258 (TU56326-holotype; DNA sample: AF259)

(Figs 3-5)

Lichenicolous ascomycete, producing ascomata through the upper and lower surface and margins of the thallus of Crocodia cf. clathrata (Figs 1C, 3A \& B).

Ascomata apothecioid, sessile, the developing fruiting bodies bursting through the cortex of the host thallus; grouped, sometimes ten or even more ascomata starting from a single base, basally constricted (Fig. 3C \& D); diameter of aggregations of immature ascomata $0.4-(0.7 \pm 0 \cdot 3)-0.8 \mathrm{~mm}(\mathrm{n}=19)$, and aggregations of mature, opened ascomata 0.6- $(1 \cdot 4 \pm 0 \cdot 4)-2 \cdot 4 \mathrm{~mm}(\mathrm{n}=16$; Fig. 3C); hemiangiocarpic, at first closed (Fig. 4C), then opening with the edge rolling outwards exposing a salmon red disc (Fig. 3C), 0·2- $(0 \cdot 3 \pm 0 \cdot 1)-0 \cdot 7 \mathrm{~mm}(\mathrm{n}=20)$. True exciple well developed, more-orless concolorous with the yellow medulla of the host lichen (Fig. 3D), textura globularis-type (Fig. 4E), c. 10-15 $\mu \mathrm{m}$ wide. Exciple surrounding hymenium and hypothecium impregnated with dark yellowish to brownish pigment grains (Fig. 4C, D \& G), this pigment does not dissolve in either Kor N, and does not autofluoresce, (Fig. 4A), and is distinct from pulvinic acid that gives the yellow colour to the host thallus (pinkish fluorescence in Fig. 4A); the hyaline hyphal tips of the external excipular cells extend out of the margin (Figs 4D \& 5A) revealing the mealy appearance of the ascomatal margin (Figs 3D \& 5A). Hymenium c. $35 \mu \mathrm{m}$ high, hyaline (Fig. 4F), without hymenial gel, the upper part covered by an amorphous hyaline layer, $\mathrm{K}-, \mathrm{K} / \mathrm{I}-, \mathrm{CRB}+$ dark blue; subhymenium slightly yellowish, textura intricata (Fig. 4F). Hypothecium hyaline, c. $160 \mu \mathrm{m}$ (until the pigmented rim), similar in structure to exciple (i.e. textura globularis-angularis type) (Fig. 4E), K-, K/I-, 
$\mathrm{CRB}+$ pale blue; sometimes with clumps of yellow pigment grains (Fig. 4C \& E). Paraphyses irregularly septate, unbranched (Fig. 4H \& L) or only dichotomously branched at the base, lax (no hymenial gel), c. $1 \mu \mathrm{m}$ wide, not or only very slightly widened at tips, remaining hyaline, but tips surrounded by a hyaline amorphous substance (forming a layer over the hymenium), CRB+ dark blue; contents of paraphyses in Congo red+ reddish (Fig. $4 \mathrm{H} \&$ L), CRB+ blue. Asci functionally unitunicate, clavate, $40-(44 \cdot 8 \pm 5 \cdot 6)-55 \times 10-(13 \cdot 2 \pm 3 \cdot 5)-20 \mu \mathrm{m}(\mathrm{n}=10)$; apical ascus wall not widened or slightly widened, non-amyloid $(\mathrm{K} / \mathrm{I}-)$ without distinct apical apparatus; the ascus base distinctly narrowed; 8 biseriate spores (Fig. $4 \mathrm{H} \&$ K). Ascospores 2-celled, hyaline, fusiform, spore tips attenuated, not constricted or only slightly constricted at septum, symmetrical or sometimes asymmetrical (one cell longer than the other), $14-(15 \cdot 8 \pm 1 \cdot 5)-19 \times 4-(4 \cdot 8 \pm 0 \cdot 8)-7 \mu \mathrm{m}, 1 / \mathrm{w}=2 \cdot 1-4 \cdot 5(\mathrm{n}=20)$, with perispore $<1 \mu \mathrm{m}$, which is Congo red-and CRB- (Fig. 4I \& J); intracellular matrix of ascospores Congo red+, CRB+ (Fig. 4I-K). Vegetative hyphae hyaline, nonamyloid, I-, K/I-, protruding between the medullary hyphae of the host (Fig. 4B). Asexual morph not observed.

Etymology. The genus name refers to the type locality, Taita Hills in Kenya; the epithet 'aurea' refers to the golden yellow colour of the ascoma margin.

Taxonomy. Monotypic genus in Gomphillaceae (Ostropales, Ostropomycetidae, Lecanoromycetes, Ascomycota).

Ecology and distribution. Obligately lichenicolous, growing on thalli of Crocodia cf. clathrata (Peltigerales). The ascomata can burst through the host thallus but no obvious damage to mycobiont or photobiont was detected by microscopic inspection. On the lower surface of the host the ascomata usually develop through pseudocyphellae (pores); however, on the upper surface and thallus margins they might develop preferentially at locations where the cortex of the host has been damaged. Inside the host, the vegetative hyphae of Taitaia are slightly narrower than those of the host (Fig. 5A \& B) and can be followed for some distance between the medullary hyphae of the host (Fig. 4B). The ascomata of Taitaia are closely associated with the internal cephalodia of the host (Figs 3D \& 5A) that contain a nitrogen-fixing cyanobacterium (Nostoc). In cephalodiate lichens, the green-algal photobiont typically produces most photosynthate and the cephalodial cyanobiont mainly fixes nitrogen (Cornejo \& Scheidegger 2013; Rikkinen 2017). While 
vegetative hyphae of the fungus are seen on cephalodial surfaces, they do not appear to penetrate into these structures.

The new taxon is known from two localities in tropical lower-mountain forests in Kenya (East Africa).

Additional specimen examined. Kenya: Taita-Taveta Province: near summit of Vuria, dense moist forest with Maesa lanceolata, Nuxia congesta and Dracaena afromontana, UTM 421443, 9623094, 2072 m, on thallus of Crocodia cf. clathrata growing on stem of woody climber, 2015, J. Rikkinen 16260 (TU 56327; DNA sample: AF260). Rift Valley Province: Cherangani Hills, Kapcherop, along Chepkait River, riverine in disturbed montane forest, $01^{\circ} 02^{\prime} \mathrm{N}, 35^{\circ} 19^{\prime} \mathrm{E}, 2200 \mathrm{~m}$, on Crocodia cf. clathrata, on bark, 2016, P. Kirika 5103 (EA; DNA sample: AF275).

Acknowledgements: We thank the staff of the Taita Research Station of the University of Helsinki. The fieldwork in Taita Hills was carried out under the National Council for Science and Technology, Kenya, permit no. NCST/RCD/17/012/33. Rasmus Puusepp is thanked for molecular work, Bellis Kullman (Tartu) for help with fluorescence microscopy, Alexander R. Schmidt and Dorothea Hause-Reitner (Göttingen) for the collaboration and assistance with light microscopy and SEM imaging, and Raquel Pino-Bodas for supplying sequences from Corticifraga peltigerae. We are grateful to the reviewers for their criticism of the manuscript. The financial support for AS was provided by IUT 20-30 and by the European Regional Development Fund (Centre of Excellence EcolChange). The project has also received funding from the European Union's Horizon 2020 research and innovation programme under grant agreement no. 705777. We also gratefully acknowledge financial support from the Academy of Finland (TAITAWATER 2012-2016) and the Department of Biosciences, University of Helsinki.

\section{REFERENCES}

Baloch, E., Lücking, R., Lumbsch, H. T. \& Wedin, M. (2010) Major clades and phylogenetic relationships between lichenized and non-lichenized lineages in Ostropales (Ascomycota: Lecanoromycetes). Taxon 59: 1483-1494.

Bock, C., Hauck, M. \& Fischer, E. (2007) The lichen flora of Rwanda: an annotated checklist. Willdenowia 37: 563-575. 
Burgess, N. D., Butynski, T. M., Cordeiro, N. J., Doggart, N. H., Fjeldsa, J., Howell, K. M., Kilahama, F. B., Loader, S. P., Lovett, J. C., Mbilinyi, B., Menegon, M., Moyer, D. C., Nashanda, E., Perkin, A., Rovero, F., Stanley, W. T. \& Stuart, S. N. (2007) The biological importance of the Eastern Arc Mountains of Tanzania and Kenya. Biological Conservation 134: 209-231. https://doi.org/10.1016/j.biocon.2006.08.015

Cornejo, C. \& Scheidegger, C. (2013) New morphological aspects of cephalodium formation in the lichen Lobaria pulmonaria (Lecanorales, Ascomycota). The Lichenologist 45: 77-87. https://doi.org/10.1017/S0024282912000631

Darriba, D., Taboada, G. L., Doallo, R. \& Posada, D. (2012) jModelTest 2: more models, new heuristics and parallel computing. Nature Methods 9: 772. doi:10.1038/nmeth.2109

Dimitrov, D., Nogués-Bravo, D. \& Scharff, N. (2012) Why Do Tropical Mountains Support Exceptionally High Biodiversity? The Eastern Arc Mountains and the Drivers of Saintpaulia Diversity. PLoS ONE 7: e48908. doi:10.1371/journal.pone.0048908

Edgar, R. C. (2004) MUSCLE: multiple sequence alignment with high accuracy and high throughput. Nucleic Acids Research 32: 1792-1797. doi:10.1093/nar/gkh340

Enroth, J., Nyqvist, P., Malombe, I., Pellikka, P. \& Rikkinen, J. (2013) Additions to the moss flora of Kenya and Taita Hills and Mount Kasigau, Kenya. Polish Botanical Journal 58: 495-510. doi: 10.2478/pbj-2013-0062

Ertz, D. (2009) Revision of the Corticolous Opegrapha Species from the Paleotropics. Bibliotheca Lichenologica 102. J. Cramer in der Gebrüder Borntraeger Verlagsbuchhandlung, Berlin and Stuttgart. 176 pp.

Etayo, J. (2010) Hongos liquenícolas de Perú: Homenaje a Rolf Santesson. Bulletin de la Société linnéenne de Provence 61: 1-46.

Etayo, J. \& Diederich, P. (2001) Gyalideopsis floridae, sp. nov. a new lichenicolous lichen from Florida (Gomphillaceae, Ascomycetes). The Bryologist 104: 130133.

Fryday, A. M. (2015) A new checklist of lichenised, lichenicolous and allied fungi reported from South Africa. Bothalia 45: 59-122. 
http://dx.doi. org/10.4102/abc.v45i1.148

Garbelotto, M. M., Lee H. K., Slaughter, G., Popenuck, T., Cobb, F. W. \& Bruns, T. D. (1997) Heterokaryosis is not required for virulence of Heterobasidion annosum. Mycologia 89: 92-102.

Gilbert, O. L., James, P. W. \& Woods, R. G. (2009) Gyalidea Lettau (1937). In The Lichens of Great Britain and Ireland (C. W. Smith, A. Aptroot, B. J. Coppins, A. Fletcher, O. L. Gilbert, P. W. James \& P. A. Wolseley (eds.)): 421-423.

Gouy, M., Guindon, S. \& Gascuel, O. (2010) SeaView version 4: a multiplatform graphical user interface for sequence alignment and phylogenetic tree building. Molecular Biology and Evolution 27: 221-224. doi:10.1093/molbev/msp259

Guindon, S., Dufayard, J.-F., Lefort. V., Anisimova, M., Hordijk. W. \& Gascuel, O. (2010) New Algorithms and Methods to Estimate Maximum-Likelihood Phylogenies: Assessing the Performance of PhyML 3.0. Systematic Biology 59: $307-321$. doi: 10.1093/sysbio/syq010

Hawksworth, D. L. \& Miadlikowska, J. (1997) New species of lichenicolous fungi occurring on Peltigera in Ecuador and Europe. Mycological Research 101: $1127-1134$.

Hawksworth, D. L. \& Santesson, R. (1990) A revision of the lichenicolous fungi previously referred to Phragmonaevia. In Contributions to Lichenology in Honour of A. Henssen (H. M. Jahns (ed.)) Bibliotheca Lichenologica 38. J. Cramer, Berlin-Stuttgart, pp. 121-143.

Henssen, A. \& Lücking, R. (2002) Morphology, anatomy, and ontogeny in the Asterothyriaceae (Ascomycota: Ostropales), a misunderstood group of lichenized fungi. Annales Botanici Fennici 39: 273-299.

Jaklitsch, W., Baral, H.-O., Lücking, R. \& Lumbsch, H. T. (2016) Syllabus of Plant Families, Volume 1/2: Ascomycota. Gebrüder Borntraeger Verlag. 322 pp.

Kondratyuk, S. Y. \& Galloway D. J. (1995) Lichenicolous fungi and chemical patterns in Pseudocyphellaria. In Studies in Lichenology with Emphasis on Chemotaxonomy, Geography and Phytochemistry. Festschrift Christian Leuckert (J.-G. Knoph, K. Schrüfer \& H. J. M. Sipman (eds.)). Bibliotheca Lichenologica. J. Cramer, Berlin, Stuttgart, pp. 327-345. 
Lawrey, J. D. \& Diederich, P. (2016) Lichenicolous fungi - worldwide checklist, including isolated cultures and sequences available. URL: http://www.lichenicolous.net [accessed: 9/5/2017].

Lücking, R., Stuart, B. L. \& Lumbsch, H. T. (2004) Phylogenetic relationships of Gomphillaceae and Asterothyriaceae: evidence from a combined Bayesian analysis of nuclear and mitochondrial sequences. Mycologia 96: 283-294. http://dx.doi.org/10.1080/15572536.2005.11832978

Lumbsch, H. T., Schmitt, I., Lücking, R., Wiklund, E. \& Wedin, M. (2007) The phylogenetic placement of Ostropales within Lecanoromycetes (Ascomycota) revisited. Mycological Research 111: 257-267. https://doi.org/10.1016/j.mycres.2007.01.006

Malombe, I., Matheka, K. W., Pócs, T. \& Patiño, J. (2016) The ecological response of epiphyllous bryophytes to human-induced edges in Afromontane fragmented forests. Journal of Bryology 38: 33-46.

doi: 10.1080/03736687.2015.1122360

Miller, M. A., Pfeiffer, W. \& Schwartz, T. (2010) Creating the CIPRES Science Gateway for inference of large phylogenetic trees In Proceedings of the Gateway Computing Environments Workshop (GCE), 14 Nov. 2010, New Orleans, LA, pp. 1-8.

Myers, N., Mittermeier, R. A., Mittermeier, C. G., da Fonseca, G. A. B. \& Kent, J. (2000) Biodiversity hotspots for conservation priorities. Nature 403: 853-858.

Pino-Bodas, R., Zhurbenko, M. P. \& Stenroos, S. (2017) Phylogenetic placement within Lecanoromycetes of lichenicolous fungi associated with Cladonia and some other genera. Persoonia 39: 91-117. https://doi.org/10.3767/persoonia.2017.39.05

Rikkinen, J. (2017) Cyanobacteria in terrestrial symbiotic systems. In Modern topics in the Phototrophic Prokaryotes - Environmental and Applied Aspects (P. Hallenbeck (ed.)). Springer, Cham, Switzerland: pp. 243-294

Ronquist, F., Teslenko, M., van der Mark, P., Ayres, D. L., Darling, A., Höhna, S., Larget, B., Liu, L., Suchard, M. A. \& Huelsenbeck, J. P. (2012) MrBayes 3.2: Efficient Bayesian Phylogenetic Inference and Model Choice Across a Large Model Space. Systematic Biology 61: 539-542. doi: 10.1093/sysbio/sys029 
Stam, Å., Enroth, J., Malombe, I., Pellikka, P. \& Rikkinen, J. (2017) Experimental transplants reveal strong environmental effects on the growth of non-vascular epiphytes in Afromontane Forests. Biotropica, in press.

doi: 10.1111/btp.12472

Stamatakis, A. (2014) RAxML version 8: a tool for phylogenetic analysis and postanalysis of large phylogenies. Bioinformatics 30: 1312-1313.

doi: 10.1093/bioinformatics/btu033.

Swinscow, T. D. V. \& Krog, H. (1988) Macrolichens of East Africa. London: British Museum (Natural History).

Talavera, G., \& Castresana, J. (2007) Improvement of phylogenies after removing divergent and ambiguously aligned blocks from protein sequence alignments. Systematic Biology 56: 564-577.

doi: https://doi.org/10.1080/10635150701472164

Tedersoo, L., Jairus, T., Horton, B.M., Abarenkov, K., Suvi, T., Saar, I. \& Kõljalg, U. (2008) Strong host preference of ectomycorrhizal fungi in a Tasmanian wet sclerophyll forest as revealed by DNA barcoding and taxon-specific primers. New Phytologist 180: 479-490. doi: 10.1111/j.1469-8137.2008.02561.x

Vězda, A. (1987) Flechtensystematische Studien XII. Die Familie Gomphillaceae und ihre Gliederung. Folia Geobotanica et Phytotaxonomica 22: 179-198.

Vilgalys, R. \& Hester, M. (1990) Rapid genetic identification and mapping of enzymatically amplified ribosomal DNA from several Cryptococcus species. Journal of Bacteriology 172: 4238-4246.

White, T. M., Bruns, T., Lee, S. \& Taylor, J. (1990) Amplification and direct sequencing of fungal ribosomal RNA for phylogenetics. In PCR protocols: $a$ guide to methods and applications (M. A. Innis, D. H Gelfand, J. J. Sninsky \& T. J. White (eds.)). Academic Press, New York, pp. 315-321,

Zhurbenko, M. (2007) Corticifraga santessonii and C. chugachiana (Lecanoromycetes, Ascomycota), new species of lichenicolous fungi from the Holarctic. The Lichenologist 39: 221-226. doi: https://doi.org/10.1017/S0024282907006317

Zoller, S., Scheidegger, C. \& Sperisen, C. (1999) PCR primers for the amplification of mitochondrial small subunit ribosomal DNA of lichen-forming ascomycetes. The Lichenologist 31: 511-516. 

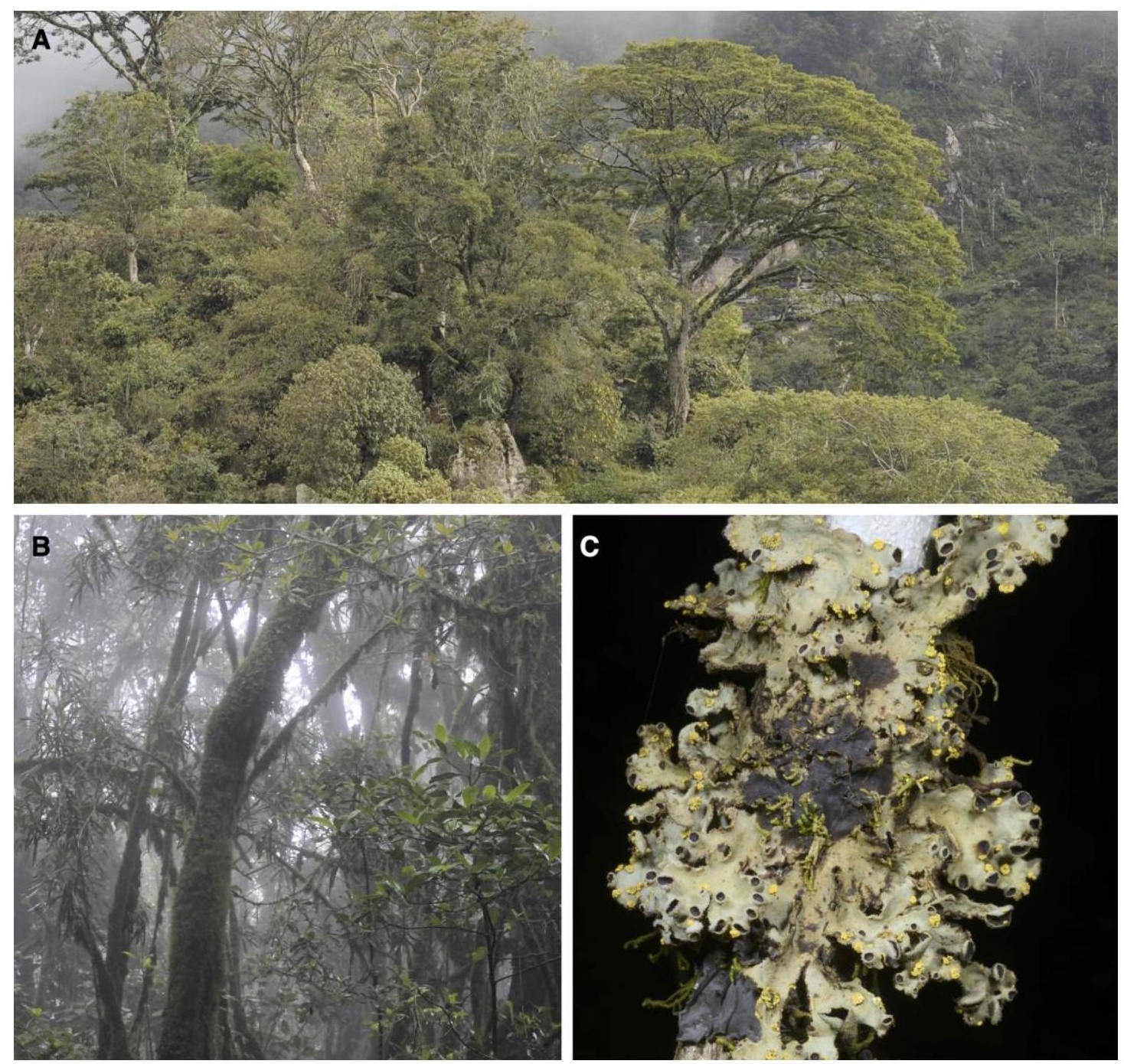

Figure 1. Habitat of Taitaia aurea in the Taita Hills, south-eastern Kenya. A, indigenous montane forest on the northfacing slope of Vuria, part of the Dawida massif; B, moss-rich forest at the type locality; C, Crocodia cf. clathrata with yellow outgrowths of T. aurea on the upper surface and thallus margins (holotype, Rikkinen 15258). 


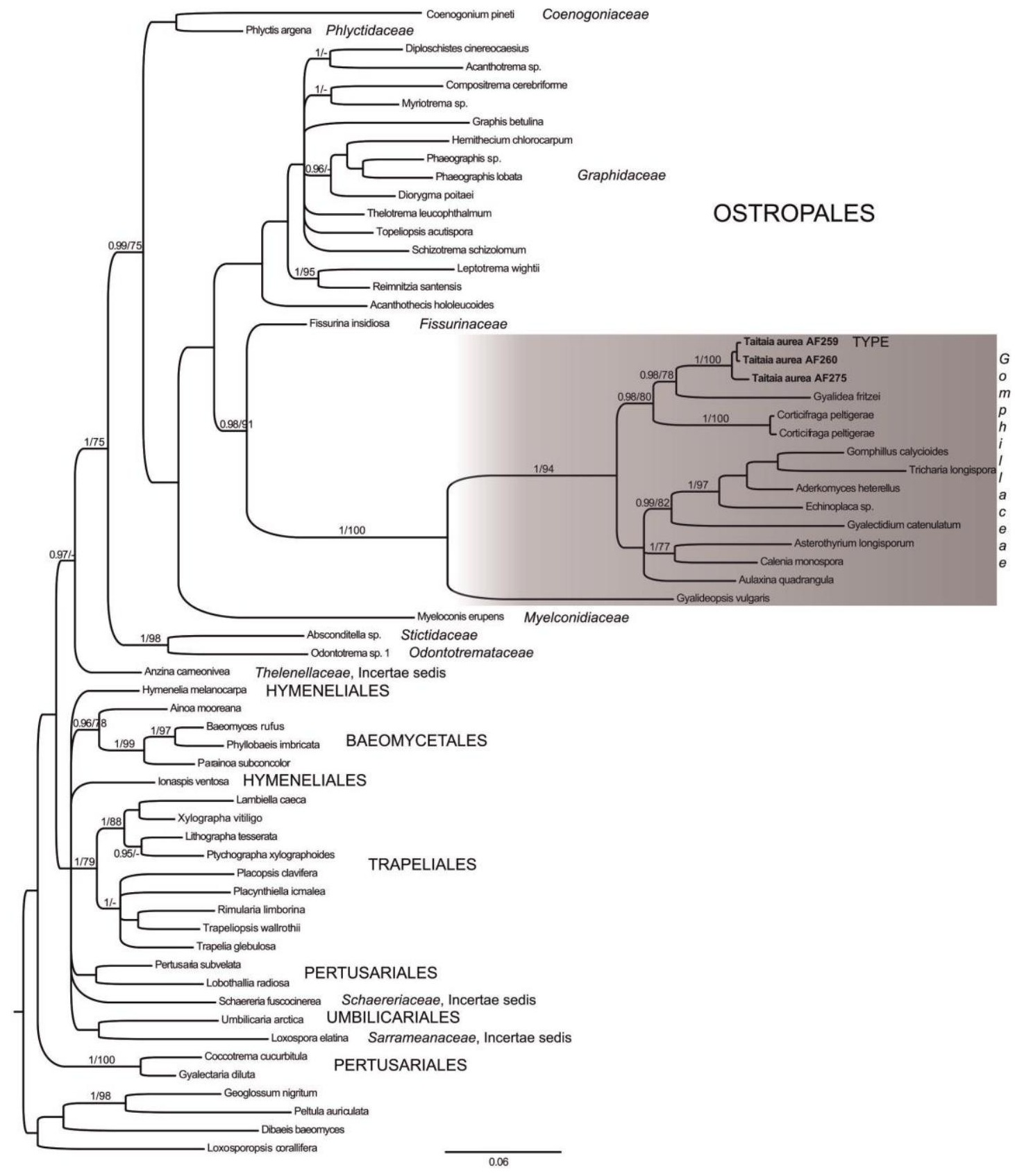

Figure 2. 50\% majority-rule consensus tree using two loci (nuLSU $+\mathrm{mtSSU}$ ) based on Bayesian approach showing the position of Taitaia aurea within Gomphillaceae, Ostropales (grey box). Numbers at nodes indicate phylogenetic relationships which are considered to be supported when posterior probabilities (PPs) are $\geq 0.95$ (before slash) and bootstrap values (BS) $\geq 75$ (after slash). 

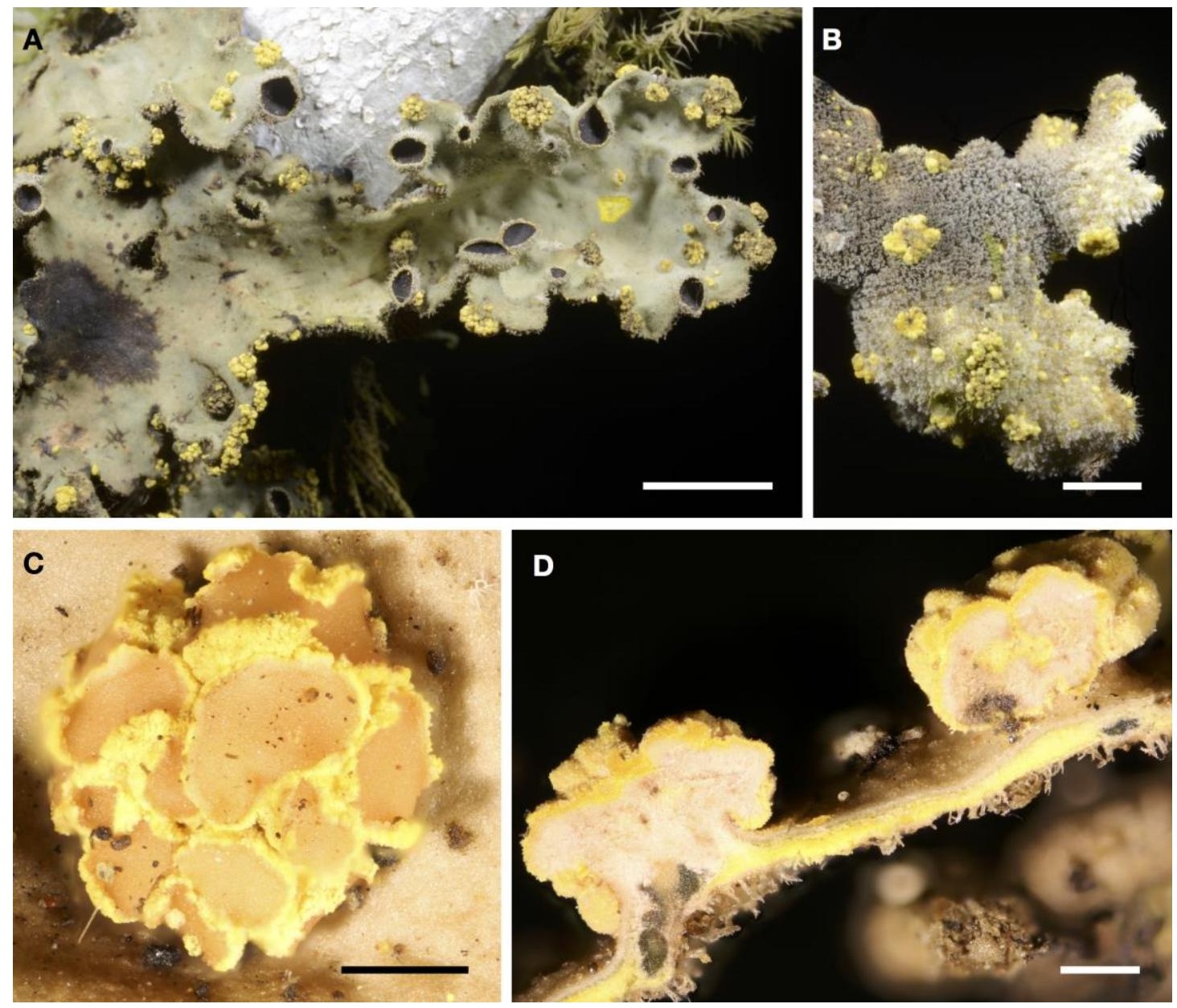

Figure 3. Taitaia aurea. A, ascomata developing on the upper surface and thallus margins of Crocodia cf. clathrata; B, ascomata developing through pseudocyphellae on the lower surface of the host; $\mathrm{C}$, group of mature ascomata; D, cross-section through two ascomata and the host thallus. A-C, Rikkinen 15258 (holotype), D, Rikkinen 15260. Scales: $A=5 \mathrm{~mm} ; B=2 \mathrm{~mm} ; C \& D=0.5 \mathrm{~mm}$. 

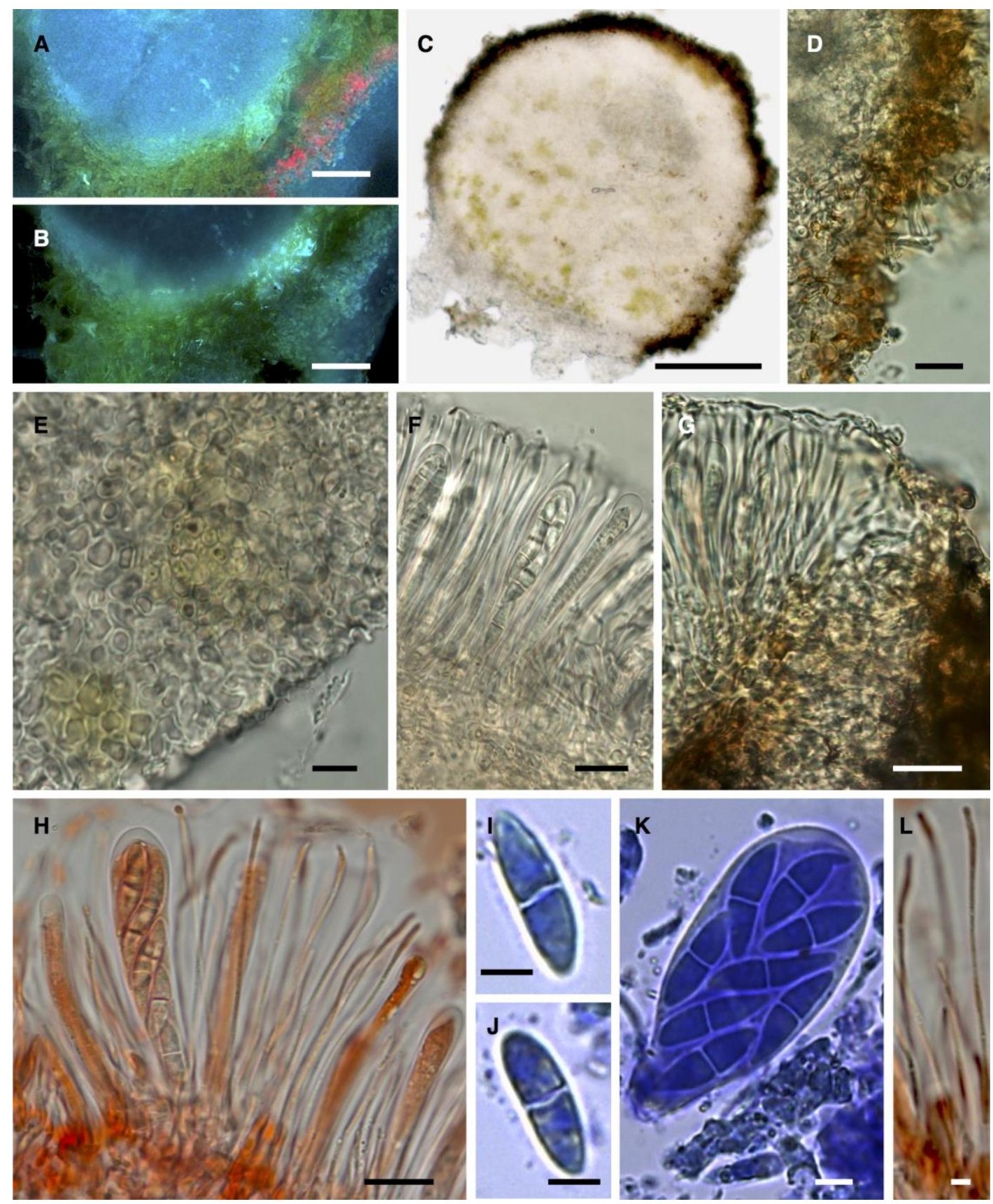

Figure 4. Taitaia aurea (Kirika 5103). A, lower part of ascoma immersed within the host thallus (note fluorescing pulvinic acid crystals using blue fluorescence filter (arrows)); B, same as A, but showing lichenicolous fungal hyphae (arrows) intruding between the hyphae of host fungus; C, cross-section through immature ascoma; D, section of exciple showing protruding hyphal tips; E, section of hyaline hypothecium of textura globulosa type; F, section of hymenium with asci and paraphyses; G, section of borderline between hymenium and exciple; $\mathrm{H}$, section of hymenium with asci and unbranched paraphyses; I \& J, ascospores; K, ascus; L, simple septate paraphyses. A-F, in water; G, H \& L, in Congo red; I-K, in Cresyl blue. Scales: A, B, $\mathrm{D}, \mathrm{F}-\mathrm{H}=10 \mu \mathrm{m} ; \mathrm{C}=40 \mu \mathrm{m} ; \mathrm{E}, \mathrm{I}-\mathrm{K}=5 \mu \mathrm{m} ; \mathrm{L}=2 \mu \mathrm{m}$. 

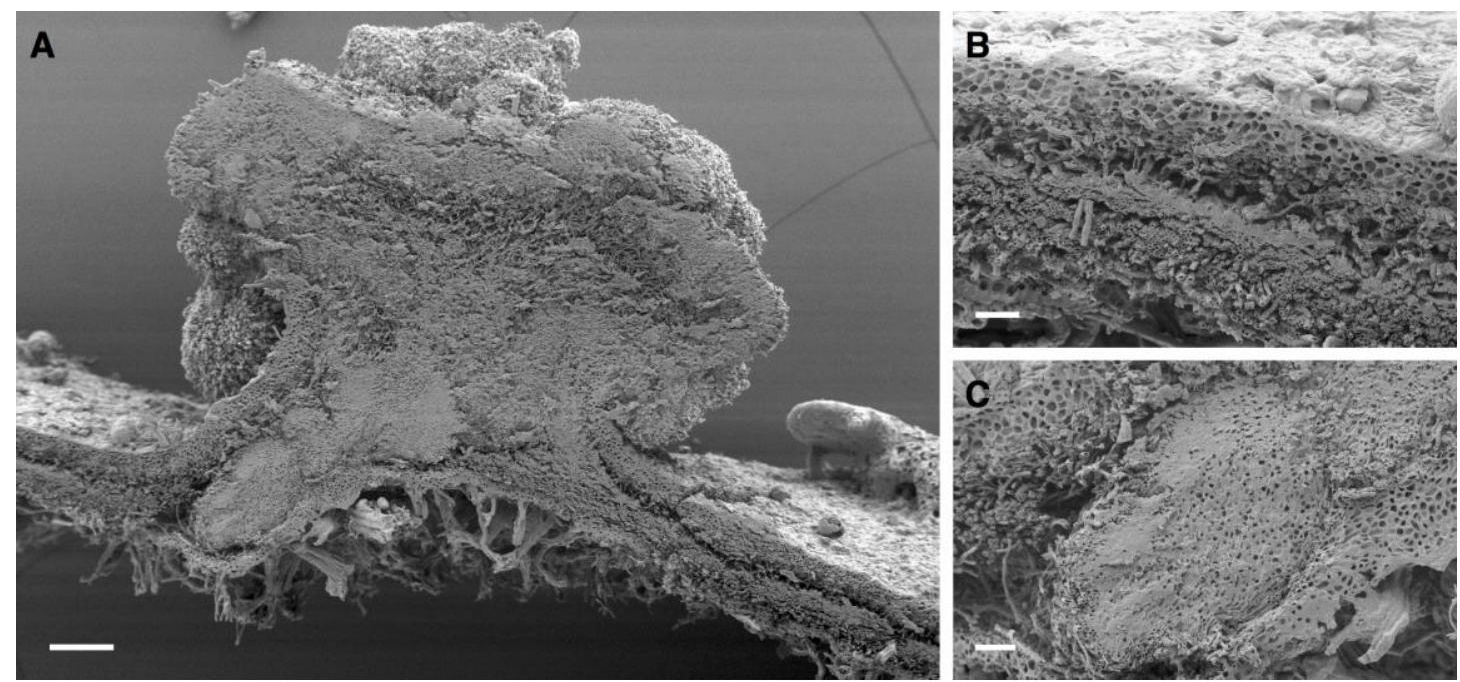

Figure 5. SEM of Taitaia aurea (Rikkinen 15260; see Fig. 3D). A, cross-section through young ascomata and host lichen. Note that the ascomata of Taitaia associate with internal cephalodia (Nostoc) of the host (arrow) and develop through its upper cortex; B, cross-section of the host showing upper cortex (c), green algal photobiont layer (p), medulla (m) and lower cortex; C, cross-section of internal cephalodium (ceph) showing superficial hyphae (arrow) which do not penetrate into the central parts of the cephalodium. Scales: $\mathrm{A}=100 \mu \mathrm{m} ; \mathrm{B} \& \mathrm{C}=20 \mu \mathrm{m}$. 
TABLE 1. GenBank Accession numbers for sequences used in this study. Newly generated sequences are in bold. Numbers in brackets are laboratory codes. The taxonomy of families follows Index Fungorum (http://www.indexfungorum.org/).

\begin{tabular}{|c|c|c|c|c|}
\hline \multirow[b]{2}{*}{ Species } & \multirow[b]{2}{*}{ Taxonomy } & \multicolumn{3}{|c|}{ GenBank Accession numbers } \\
\hline & & $\mathrm{mtSSU}$ & nuLSU & ITS \\
\hline Absconditella sp. & Stictidaceae, Ostropales & KR017331 & KR017188 & - \\
\hline Acanthothecis hololeucoides & Graphidaceae, Ostropales & JX420952 & JX421423 & - \\
\hline Acanthotrema sp. & Graphidaceae, Ostropales & KF688506 & KF688492 & - \\
\hline Aderkomyces heterellus & Gomphillaceae, Ostropales & KF833342 & KF833330 & - \\
\hline Ainoa mooreana & Baeomycetaceae, Baeomycetales & KJ462394 & KJ462339 & - \\
\hline Anzina carneonivea & Thelenellaceae, Incertae sedis & AY212851 & AY212829 & - \\
\hline Asterothyrium longisporum & Gomphillaceae, Ostropales & AY341363 & AY341349 & - \\
\hline Aulaxina quadrangula & Gomphillaceae, Ostropales & AY341364 & AY341350 & - \\
\hline Baeomyces rufus & Baeomycetaceae, Baeomycetales & KJ462396 & KJ462341 & - \\
\hline Calenia monospora & Gomphillaceae, Ostropales & KF833339 & KF833327 & - \\
\hline Coccotrema cucurbitula & Coccotremataceae, Pertusariales & AF329161 & AF274092 & - \\
\hline Coenogonium pineti & Coenogoniaceae, Ostropales & KR017337 & KR017237 & - \\
\hline Compositrema cerebriforme & Graphidaceae, Ostropales & JX421017 & JX421471 & - \\
\hline Corticifraga peltigerae & Gomphillaceae, Ostropales & - & KY462801 & - \\
\hline Corticifraga peltigerae & Gomphillaceae, Ostropales & KY661684 & KY661661 & - \\
\hline Dibaeis baeomyces & Icmadophilaceae, Pertusariales & KJ462397 & KJ462342 & - \\
\hline Diorygma poitaei & Graphidaceae, Ostropales & HQ639596 & HQ639627 & - \\
\hline Diploschistes cinereocaesius & Graphidaceae, Ostropales & DQ912306 & DQ883799 & - \\
\hline Echinoplaca sp. & Gomphillaceae, Ostropales & KF833340 & KF833328 & - \\
\hline Fissurina insidiosa & Fissurinaceae, Ostropales & KR017325 & KR017185 & - \\
\hline Geoglossum nigritum & Geoglossomycetes & AY544740 & AY544650 & - \\
\hline Gomphillus calycioides & Gomphillaceae, Ostropales & KF833341 & KF833329 & - \\
\hline Graphis betulina & Graphidaceae, Ostropales & KF875562 & KF875541 & - \\
\hline Gyalectaria diluta & Coccotremataceae, Pertusariales & KR017332 & KR017189 & - \\
\hline Gyalectidium catenulatum & Gomphillaceae, Ostropales & KF833335 & KF833323 & - \\
\hline Gyalidea fritzei & Gomphillaceae, Ostropales & HM244744 & HM244767 & - \\
\hline Gyalideopsis vulgaris & Gomphillaceae, Ostropales & AY584618 & AY584649 & - \\
\hline Hemithecium chlorocarpum & Graphidaceae, Ostropales & HQ639595 & HQ639651 & - \\
\hline Hymenelia melanocarpa & Hymeneliaceae, Hymeneliales & KJ462398 & KJ462343 & - \\
\hline Ionaspis ventosa & Hymeneliaceae, Hymeneliales & KR017322 & KR017181 & - \\
\hline Lambiella caeca & Xylographaceae, Baeomycetales & KR017338 & KR017216 & - \\
\hline Leptotrema wightii & Graphidaceae, Ostropales & EU075574 & EU075622 & - \\
\hline Lithographa tesserata & Trapeliaceae, Trapeliales & KR017327 & KR017186 & - \\
\hline Lobothallia radiosa & Megasporaceae, Pertusariales & KJ766430 & KJ766596 & - \\
\hline Loxospora elatina & Sarrameanaceae, Incertae sedis & KR017350 & KR017192 & - \\
\hline Loxosporopsis corallifera & Pertusariaceae, Pertusariales & KR017381 & KR017219 & - \\
\hline Myeloconis erumpens & Myeloconidiaceae, Ostropales & KJ449328 & KJ449338 & - \\
\hline Myriotrema sp. & Graphidaceae, Ostropales & JX421091 & JX421522 & - \\
\hline Odontotrema sp. 1 & Odontotremataceae, Ostropales & HM244751 & HM244771 & - \\
\hline Parainoa subconcolor & Incertae sedis, Baeomycetales & KR017412 & KR017236 & - \\
\hline
\end{tabular}


Peltula auriculata

Pertusaria subvelata

Phaeographis lobata

Phaeographis sp.

Phlyctis argena

Phyllobaeis imbricata

Placopsis clavifera

Placynthiella icmalea

Ptychographa xylographoides

Reimnitzia santensis

Rimularia limborina

Schaereria fuscocinerea

Schizotrema schizolomum

Taitaia aurea (AF259)

Taitaia aurea (AF260)

Taitaia aurea (AF275)

Thelotrema leucophthalmum

Topeliopsis acutispora

Trapelia glebulosa

Trapeliopsis wallrothii

Tricharia longispora

Umbilicaria arctica

Xylographa vitiligo
Lichinomycetes

Pertusariaceae, Pertusariales

Graphidaceae, Ostropales

Graphidaceae, Ostropales

Phlyctidaceae, Ostropales

Baeomycetaceae, Baeomycetales

Trapeliaceae, Trapeliales

Trapeliaceae, Trapeliales

Trapeliaceae, Trapeliales

Graphidaceae, Ostropales

Trapeliaceae, Trapeliales

Schaereriaceae, Incertae sedis

Graphidaceae, Ostropales

Gomphillaceae, Ostropales

Gomphillaceae, Ostropales

Gomphillaceae, Ostropales

Graphidaceae, Ostropales

Graphidaceae, Ostropales

Trapeliaceae, Trapeliales

Trapeliaceae, Trapeliales

Gomphillaceae, Ostropales

Umbilicariaceae, Umbilicariales

Xylographaceae, Baeomycetales
DQ922953 DQ832330

KR017389 KR017227

DQ431984 DQ431944

DQ431959 DQ431959

DQ986880 DQ986771

DQ986895 DQ986781

KU844527 KU844591

AY212870 EU940160

KJ462403 KJ462348

HQ639622 HQ639664

KR017368 KR017215

KR017384 KR017225

JX421328 FJ708492

MF372796 MF372800

MF372798 MF509277 MF372801

MF372799 MF372797

JX421374 JX421658

KF875557 JX421675

KR017354 KR017159

KR017410 KR017235

AY341374 AY341360

DQ986872 DQ986772

KJ462458 KJ462391 